\title{
Expression of epithelial-mesenchymal transition and cancer stem cell markers in colorectal adenocarcinoma: Clinicopathological significance
}

\author{
JI EUN CHOI ${ }^{1}$, JUN SANG BAE ${ }^{2}$, MYOUNG JAE KANG ${ }^{2}$, MYOUNG JA CHUNG ${ }^{2}$, \\ KYU YUN JANG ${ }^{2}$, HO SUNG PARK ${ }^{2}$ and WOO SUNG MOON ${ }^{2}$
}

\author{
${ }^{1}$ Department of Pathology, Daejeon St. Mary's Hospital, College of Medicine, The Catholic University of Korea, Jung-gu, \\ Daejeon 34943; ${ }^{2}$ Department of Pathology, Chonbuk National University, Medical School, Research Institute \\ of Clinical Medicine of Chonbuk National University-Biomedical Research Institute of Chonbuk National \\ University Hospital and Research Institute for Endocrine Sciences, Jeonju 561-756, Republic of Korea
}

Received January 23, 2017; Accepted June 16, 2017

DOI: $10.3892 /$ or.2017.5790

\begin{abstract}
Epithelial-mesenchymal transition (EMT) is known to be associated with cancer progression, metastatic spread, and therapeutic resistance and to occur at the invasive front. Cancer stem cells (CSCs) display stemness features and might be implicated in tumor initiation, local recurrence and metastasis. The present study was conducted to examine the expression status and relationships between EMT- and CSC-related proteins in the different tumor areas of primary colorectal cancer (CRC), along with their clinicopathological significance. We performed immunohistochemical staining for 4 EMT-related proteins, namely E-cadherin, $\beta$-catenin, snail and vimentin, and two CSC-related proteins, namely CD44 and CD133, in two different tumor areas (the representative tumor center and the deepest invasive front) in 286 cases of primary CRC using tissue microarrays. Altered expression of all EMT-related proteins was more frequently observed in the invasive front than in the tumor center. Altered expression of E-cadherin, $\beta$-catenin and vimentin significantly associated with aggressive tumor characteristics. In particular, loss of E-cadherin expression in the invasive front significantly associated with shorter disease-free survival (DFS, $\mathrm{P}=0.002$ ) and overall survival $(\mathrm{OS}, \mathrm{P}=0.007)$. Overexpression of vimentin in the invasive front significantly correlated with poor OS $(\mathrm{P}=0.028)$. Loss of $\mathrm{CD} 44$ expression both in the tumor center and in the invasive front significantly associated with unfavorable clinicopathological characteristics. In the invasive front, but not in the tumor center, combination of the altered protein
\end{abstract}

Correspondence to: Professor Woo Sung Moon, Department of Pathology, Chonbuk National University, Medical School, 567 Baekje-daero, Deokjin-gu, Jeonju, Jeollabuk-do 54896, Republic of Korea

E-mail: mws@jbnu.ac.kr

Key words: colorectal carcinoma, cancer stem cells, epithelialmesenchymal transition expression patterns of E-cadherin, $\beta$-catenin, vimentin, snail and CD133 significantly associated with aggressive clinicopathological factors and shorter DFS $(\mathrm{P}=0.003)$ and OS $(\mathrm{P}=0.005)$. The present data suggest that cancer cells expressing a combination of altered EMT- and CSC-related proteins may represent a potential biomarker for aggressive tumor behavior and may be a possible future candidate for molecular targeted treatments for CRC.

\section{Introduction}

Colorectal cancer (CRC) is the third most common cancer worldwide. Although the mortality rate of CRC has been decreasing, owing largely to early clinical detection and improved management in developed countries, it is still the fourth most common cause of cancer-related deaths (1). Tumor recurrence and chemo-resistance are the main causes of these poor outcomes, and hence, identification of new therapeutic targets has become essential.

Epithelial-mesenchymal transition (EMT) is a unique process in which cells lose epithelial features and gain mesenchymal properties (2). During EMT, the epithelial cells lose cell-to-cell contact and cell polarity, thereby acquiring increased motility and invasiveness (3). The process of EMT is associated with the downregulation of epithelial markers and aberrant upregulation of mesenchymal markers (4). E-cadherin is the most significant mediator of cell-to-cell adhesion in epithelial tissue, and loss of E-cadherin in epithelial cells is a critical step in EMT $(5,6)$. Furthermore, snail is a transcriptional repressor of E-cadherin that silences its gene expression (7) and $\beta$-catenin binds to E-cadherin in the cell membrane (6). During EMT, downregulation of E-cadherin is associated with the release of $\beta$-catenin, which is consequently translocated to the nucleus where it activates the WNT signaling pathway (6). Additionally, cells that have undergone EMT often express mesenchymal proteins such as vimentin (8).

Many studies have reported that EMT is associated with cancer progression, metastatic spread and therapeutic 
resistance (9-12). Although EMT processes have been documented in many in vitro cancercell models, the significance of EMT during cancer progression and its relevance in human cancer tissues remains controversial (13). While EMT has been studied in human CRC, the clinical significance of EMT in CRC has not been clearly elucidated (5,6,14-18). In addition, some studies have reported that EMT occurs at the invasive front of human cancer tissue $(16,19)$. However, the differences in EMT-related protein expression patterns among different tumor areas (tumor center vs. invasive front) and their clinicopathologic significance have not been evaluated in CRC.

Although mesenchymal traits appear to enable the dissemination of cancer cells from the primary tumor site, they need to acquire self-renewal capability to successfully establish heterogeneous metastases, a feature similar to that exhibited by stem cells (3). Cancer stem cells (CSCs) display stemness features, which include self-renewal, unlimited proliferative potential and multipotency, and might be responsible for tumor initiation and development, as well as local relapses and metastasis (20).

Several markers for CSCs have been investigated in CRC, with CD44 and CD133 being the most frequently researched and believed to be the main colorectal CSC markers $(21,22)$. CD44, a cell adhesion molecule, is known to be involved in cell growth, differentiation and survival (22), whereas CD133 is a transmembrane and cell surface protein that is known to be associated with recurrence-free survival and chemo-resistance in CRC (22). However, some controversies still exist over the relationship between expression of CD44 and CD133 and their associations with clinicopathological factors and prognosis of CRC (21).

In the present study, the expression status of EMT- and CSC-related proteins in different tumor areas (tumor center vs. invasive front) and their clinicopathological significance were assessed in 286 primary CRC tissues using immunohistochemistry. Moreover, the effect of their combined expression patterns on clinical and pathological features and patient outcomes were analyzed.

\section{Materials and methods}

Patient and tissue samples. The CRC tissue samples were retrieved from the archives maintained at the Department of Pathology at Chonbuk National University from 2006 to 2007. A total of 286 eligible patients who had undergone surgical resection with lymph node dissection were identified, according to the following criteria: availability of hematoxylin and eosin-stained glass slides and paraffin blocks for construction of a tissue microarray, and no preoperative chemotherapy or radiotherapy. The CRC specimens and patients' medical records were reviewed to obtain clinical and pathologic data, including age, sex, tumor size, depth of invasion, tumor differentiation by the World Health Organization classification (23), presence of lymphovascular invasion, presence of perineural invasion, presence of lymph node metastasis, pTNM stage according to the American Joint Committee on Cancer (AJCC) 7th edition (24), postoperative recurrence or tumor metastasis, and postoperative chemotherapy or radiation therapy data. Sixty-seven patients received adjuvant chemotherapy, five patients received both adjuvant chemotherapy and radiation therapy, and 219 patients received no adjuvant treatment.

The patients were aged between 30 and 88 years (mean, 63.4 years) at the time of surgical resection, and included 174 men and 112 women. The follow-up period was determined from the date of initial surgery to the date of the last follow-up or mortality. Follow-up information, including patient outcome and the time interval between the date of surgical resection and death, tumor recurrence, or metastasis, was collected. The follow-up period ranged from 0.7 to 100 months (median, 53.0 months).

The present study obtained institutional review board approval from the Chonbuk National University Hospital (IRB number, CUH 2015-09-023). Each patient provided written informed consent. All experiments were performed in accordance with the relevant guidelines and regulations.

Tissue microarray and immunohistochemical staining. Tissue microarrays were constructed for immunohistochemical staining. The original hematoxylin and eosin-stained slides were reviewed, and representative tumor center (the most representative solid area composed of intact tumor cells in the middle of the tumor) and invasive front (the deepest tumor area with the highest tumor budding) areas were marked for tissue microarray creation. Four cylinders of $2 \mathrm{~mm}$ (two from the tumor center, one from the cancer invasion front, and one from the adjacent non-tumor mucosa) were obtained from all individual cases.

Immunohistochemical staining was performed on 4- $\mu$ m-thick sections of tissue microarray blocks from the 286 included surgically resected samples. The tissue sections were deparaffinized and rehydrated following the standard procedure. Heat-induced antigen retrieval was performed in a microwave oven for $20 \mathrm{~min}$, and the sections were incubated for $30 \mathrm{~min}$ along with primary antibodies. The primary antibodies used were against E-cadherin (clone 36B5, 1:50 dilution; Novocastra Laboratories Ltd., Newcastle, UK), $\beta$-catenin (clone 14/ $\beta$-catenin, 1:200 dilution; BD Biosciences, San Jose, CA, USA), vimentin (clone V9, 1:100 dilution; Novocastra Laboratories), snail (clone snail1 + snail2, 1:100 dilution; Abcam, Cambridge, UK), CD44 (clone DF1485, 1:100 dilution; Dako, Glostrup, Denmark) and CD133 (clone AC133, 1:50 dilution; Miltenyi Biotec, Inc., Auburn, CA, USA). All immunohistochemical staining was performed by a polymer intense detection system using the BondMax Automatic stainer (Leica Microsystems, Inc., Bannockburn, IL, USA) in accordance with the manufacturer's instructions.

Evaluation of immunohistochemistry. For E-cadherin, $\beta$-catenin and CD44, only the membranous staining was evaluated $(4,25)$. Vimentin was considered a cytoplasmic protein (4), while snail was evaluated for either cytoplasmic or nuclear staining (5). CD133 staining was considered to indicate either the apical portion of the tumor cells or the shed cellular debris in the tumor glands $(21,25,26)$. All samples were semiquantitatively scored by evaluation of the proportion of positive tumor cells over the total number of tumor cells (percentage of positive tumor cells per tissue microarray punch, $5 \%$ intervals, range, $0-100 \%)$. From each case, the average score of two 
A

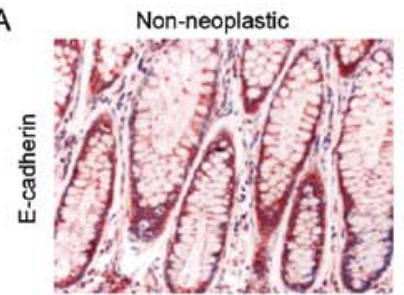

D

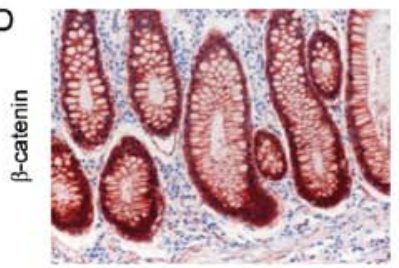

G

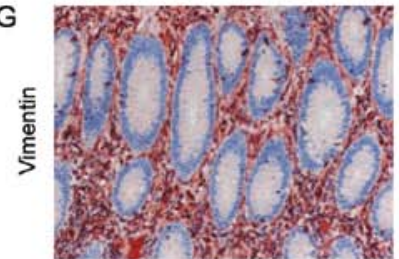

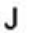

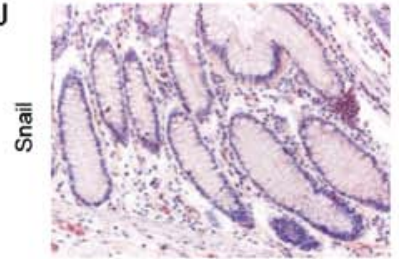

M

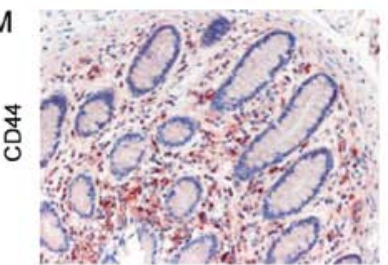

P

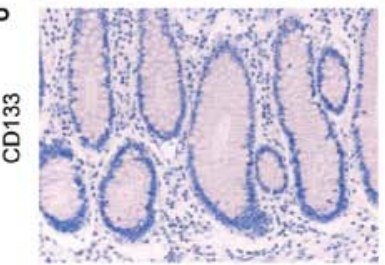

B

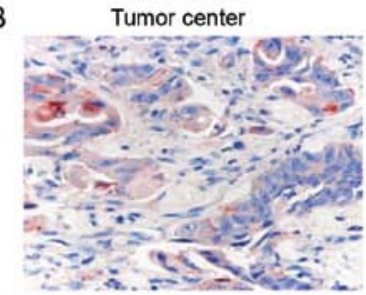

E
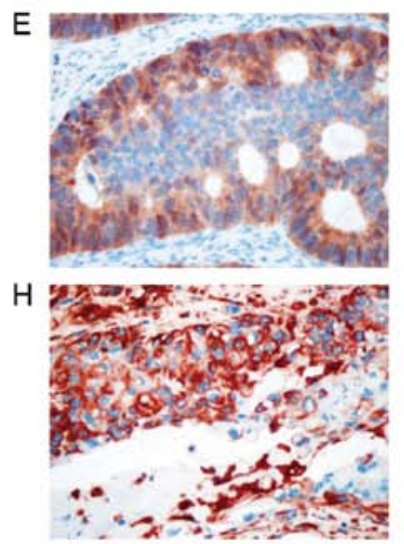

$\mathrm{K}$

\section{b}

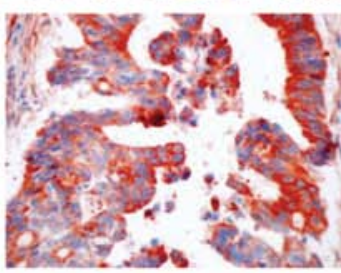

$\mathrm{N}$

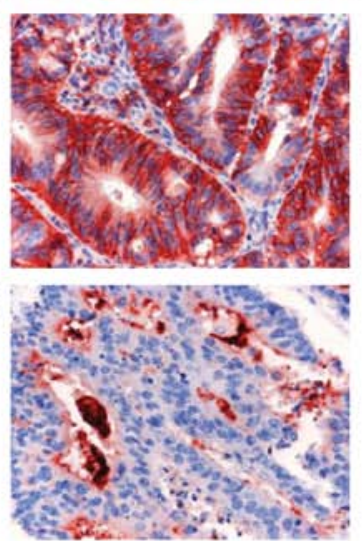

C

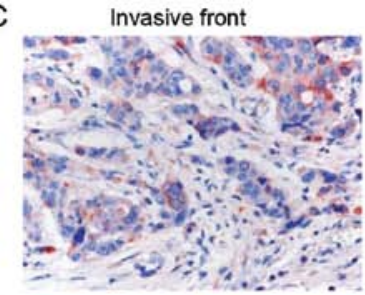

F
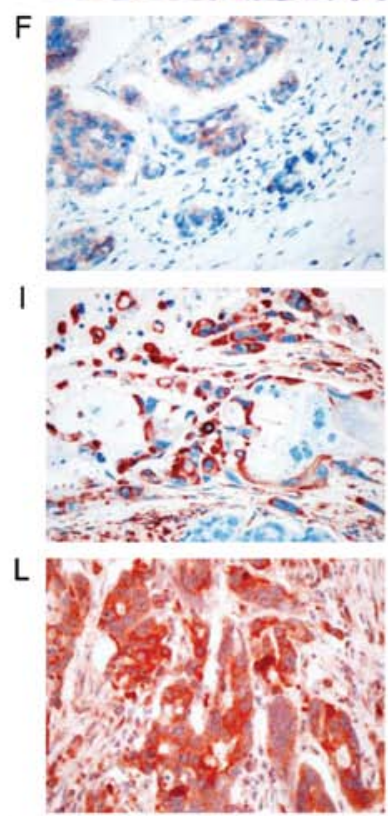

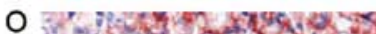

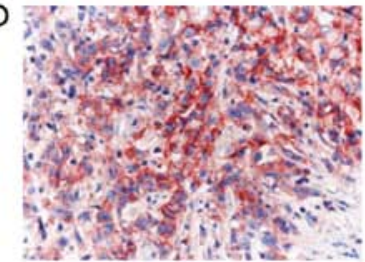

$\mathrm{R}$

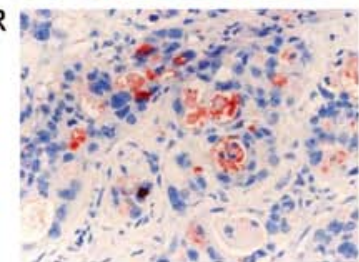

Figure 1. Immunohistochemical analysis of the expression of epithelial-mesenchymal transition (EMT)-related and cancer stem cell (CSC)-related proteins (first column: original magnification, x200; second and third columns: original magnification, $\mathrm{x} 400$ ). The first, second and third columns show non-neoplastic mucosa, the tumor center, and the invasive front, respectively. (A-C) E-cadherin, (D-F) $\beta$-catenin, (G-I) vimentin, (J-L) snail, (M-O) CD44 and (P-R) CD133.

tissue microarray tumor center cores was used for the analysis. Subsequently, using receiver-operating characteristic (ROC) curve analysis, appropriate cut-off scores for each marker were obtained. Positive staining in the percentages of cells above or below the cut-off scores were classified as 'overexpression' or 'loss of expression', respectively.

Statistical analysis. Comparisons between individual or combinations of EMT- and CSC-related markers and clinicopathologic characteristics were assessed using the $\chi^{2}$ test. The Kaplan-Meier method with the log-rank test was used for univariate analysis of the effects of individual and combined EMT- and CSC-related markers for predicting patient diseasefree survival (DFS) and overall survival (OS). To determine the combination effects of the EMT- and CSC-related markers on the clinicopathologic characteristics and predicting patient outcome, 66 combinations were evaluated using the $\chi^{2}$ test and Kaplan-Meier method with the log-rank test. Multivariate analysis was performed using a Cox proportional hazards model to determine hazard ratios. For all analyses, $\mathrm{P}<0.05$ were considered to indicate statistical significance. Statistical analysis was performed with SPSS software (SPSS Standard version 21.0; SPSS, Inc., Chicago, IL, USA).

\section{Results}

Associations between each protein expression, clinicopathologic characteristics and patient outcome

E-cadherin. E-cadherin was strongly expressed in the membrane of non-neoplastic colorectal epithelial cells. 
Table I. Clinicopathological characteristics and correlation with the epithelial-mesenchymal transition (EMT)-related protein expression status in the tumor center.

\begin{tabular}{|c|c|c|c|c|c|c|c|c|}
\hline \multirow[b]{2}{*}{ Characteristics (n) } & \multicolumn{4}{|c|}{ Loss of expression } & \multicolumn{4}{|c|}{ Overexpression } \\
\hline & $\begin{array}{l}\text { E-cadherin } \\
(\mathrm{n}=171) \\
(\%)\end{array}$ & P-value & $\begin{array}{c}\beta \text {-catenin } \\
(\mathrm{n}=102) \\
(\%)\end{array}$ & P-value & $\begin{array}{l}\text { Vimentin } \\
(\mathrm{n}=40) \\
(\%)\end{array}$ & P-value & $\begin{array}{c}\text { Snail } \\
(\mathrm{n}=149) \\
(\%)\end{array}$ & P-value \\
\hline Age (years) & & 0.038 & & 0.391 & & 0.137 & & 0.177 \\
\hline$<60(99)$ & $51(51.5)$ & & $32(32.3)$ & & $18(18.2)$ & & $57(57.6)$ & \\
\hline$\geq 60(187)$ & $120(64.2)$ & & $70(37.4)$ & & $22(11.8)$ & & $92(49.2)$ & \\
\hline Sex & & 0.026 & & 0.623 & & 0.010 & & 0.932 \\
\hline Female (112) & $76(67.9)$ & & $38(33.9)$ & & $23(20.5)$ & & $58(51.8)$ & \\
\hline Male (174) & $95(54.6)$ & & $64(36.8)$ & & $17(9.8)$ & & $91(52.3)$ & \\
\hline Size $(\mathrm{cm})$ & & 0.012 & & 0.974 & & 0.255 & & 0.590 \\
\hline$<4(109)$ & $55(50.5)$ & & $39(35.8)$ & & $12(11.0)$ & & $59(54.1)$ & \\
\hline$\geq 4(177)$ & $116(65.5)$ & & $63(35.6)$ & & $28(15.8)$ & & $90(50.8)$ & \\
\hline Histologic grade & & $<0.001$ & & $<0.001$ & & $<0.001$ & & 0.653 \\
\hline Low (249) & $138(55.4)$ & & $76(30.5)$ & & $23(9.2)$ & & $131(52.6)$ & \\
\hline High (37) & $33(89.2)$ & & $26(70.3)$ & & $17(45.9)$ & & $18(48.6)$ & \\
\hline $\begin{array}{l}\text { Depth of invasion } \\
\text { (pT category) }\end{array}$ & & 0.048 & & 0.592 & & 0.038 & & 0.044 \\
\hline $\mathrm{T} 1$ or $\mathrm{T} 2(65)$ & $32(49.2)$ & & $25(38.5)$ & & $4(6.2)$ & & $41(63.1)$ & \\
\hline $\mathrm{T} 3$ or T4 (221) & $139(62.9)$ & & $77(34.8)$ & & $36(16.3)$ & & $108(48.9)$ & \\
\hline Lymphovascular invasion & & 0.009 & & 0.007 & & 0.036 & & 0.227 \\
\hline Absent (165) & $88(53.3)$ & & $48(29.1)$ & & $17(10.3)$ & & $91(55.2)$ & \\
\hline Present (121) & $83(68.6)$ & & $54(44.6)$ & & $23(19.0)$ & & $58(47.9)$ & \\
\hline Perineural invasion & & 0.013 & & 0.509 & & $<0.001$ & & 0.685 \\
\hline Absent (214) & $119(55.6)$ & & $74(34.6)$ & & $20(9.3)$ & & $110(51.4)$ & \\
\hline Present (72) & $52(82.2)$ & & $28(38.9)$ & & $20(27.8)$ & & $39(54.2)$ & \\
\hline Lymph node metastasis & & $<0.001$ & & 0.012 & & 0.004 & & 0.385 \\
\hline Absent (160) & $81(50.6)$ & & $47(29.4)$ & & $14(8.8)$ & & $87(54.4)$ & \\
\hline Present (126) & $90(71.4)$ & & $55(43.7)$ & & $26(20.6)$ & & $62(49.2)$ & \\
\hline pTNM stage & & $<0.001$ & & 0.034 & & 0.004 & & 0.136 \\
\hline I and II (153) & $76(49.7)$ & & $46(30.1)$ & & $13(8.5)$ & & $86(56.2)$ & \\
\hline III and IV (133) & $95(71.4)$ & & $56(42.1)$ & & $27(20.3)$ & & $63(47.4)$ & \\
\hline $\begin{array}{l}\text { Recurrence or metastasis } \\
\text { after surgery }\end{array}$ & & 0.684 & & 0.505 & & 0.486 & & 0.672 \\
\hline Absent (233) & $138(59.2)$ & & $81(34.8)$ & & $31(13.3)$ & & $120(51.5)$ & \\
\hline Present (53) & $33(62.3)$ & & $21(39.6)$ & & $9(17.0)$ & & $29(54.7)$ & \\
\hline $\begin{array}{l}\text { Recurrence or metastasis } \\
\text { after adjuvant } \\
\text { chemotherapy }\end{array}$ & & 0.812 & & 0.409 & & 0.543 & & 0.217 \\
\hline Absent (46) & $32(69.6)$ & & $17(37.0)$ & & $10(21.7)$ & & $21(45.7)$ & \\
\hline Present (21) & $14(66.7)$ & & $10(47.6)$ & & $6(28.6)$ & & $13(61.9)$ & \\
\hline
\end{tabular}

CRC cells showed diffuse membranous staining or loss of membrane expression (Fig. 1). The optimal cut-off score, based on ROC curve analysis, was determined as $\geq 95 \%$. Among the analyzed cases, diffuse membranous staining in $>95 \%$ of tumor cells was observed in the tumor center in
$115(40.2 \%)$ cases and in the invasive front in 78 (27.3\%) cases. Conversely, loss of membranous E-cadherin expression ( $<95 \%$ staining, as defined by ROC curve analysis) was observed in the tumor center in $171(59.8 \%)$ cases and in the invasive front in $208(72.7 \%)$ cases. Loss of E-cadherin expression 
Table II. Clinicopathologic characteristics and correlation with the epithelial-mesenchymal transition (EMT)-related protein expression status in the invasive front.

\begin{tabular}{|c|c|c|c|c|c|c|c|c|}
\hline \multirow[b]{2}{*}{ Characteristics (n) } & \multicolumn{4}{|c|}{ Loss of expression } & \multicolumn{4}{|c|}{ Overexpression } \\
\hline & $\begin{array}{c}\text { E-cadherin } \\
(\mathrm{n}=208) \\
(\%)\end{array}$ & P-value & $\begin{array}{c}\beta \text {-catenin } \\
(\mathrm{n}=123) \\
(\%)\end{array}$ & P-value & $\begin{array}{c}\text { Vimentin } \\
(\mathrm{n}=72) \\
(\%)\end{array}$ & P-value & $\begin{array}{c}\text { Snail } \\
(\mathrm{n}=182) \\
(\%)\end{array}$ & P-value \\
\hline Age (years) & & 0.094 & & 0.692 & & 0.146 & & 0.196 \\
\hline$<60(99)$ & $66(66.7)$ & & $41(41.4)$ & & $30(30.3)$ & & $68(68.7)$ & \\
\hline$\geq 60(187)$ & $142(75.9)$ & & $82(43.9)$ & & $42(22.5)$ & & $114(61.0)$ & \\
\hline Sex & & 0.335 & & 0.308 & & 0.105 & & 0.749 \\
\hline Female (112) & $85(75.9)$ & & $44(39.3)$ & & $34(30.4)$ & & $70(62.5)$ & \\
\hline Male (174) & $123(70.7)$ & & $79(45.4)$ & & $38(21.8)$ & & $112(64.4)$ & \\
\hline Size $(\mathrm{cm})$ & & 0.011 & & 0.148 & & 0.018 & & 0.154 \\
\hline$<4(109)$ & $70(64.2)$ & & $41(37.6)$ & & $19(17.4)$ & & $75(68.8)$ & \\
\hline$\geq 4(177)$ & $138(78.0)$ & & $82(46.3)$ & & $53(29.9)$ & & $107(60.5)$ & \\
\hline Histologic grade & & 0.001 & & 0.004 & & $<0.001$ & & 0.868 \\
\hline Low (249) & $173(69.5)$ & & $99(39.8)$ & & 49 (19.7) & & $158(63.5)$ & \\
\hline High (37) & 35 (94.6) & & $24(64.9)$ & & $23(62.2)$ & & $24(64.9)$ & \\
\hline $\begin{array}{l}\text { Depth of invasion } \\
\text { (pT category) }\end{array}$ & & 0.001 & & 0.400 & & 0.039 & & 0.052 \\
\hline $\mathrm{T} 1$ or $\mathrm{T} 2(65)$ & 37 (56.9) & & $25(38.5)$ & & $10(15.4)$ & & $48(73.8)$ & \\
\hline $\mathrm{T} 3$ or $\mathrm{T} 4(221)$ & $171(77.4)$ & & $98(44.3)$ & & $62(28.1)$ & & $134(60.6)$ & \\
\hline Lymphovascular invasion & & $<0.001$ & & $<0.001$ & & 0.004 & & 0.455 \\
\hline Absent (165) & $106(64.2)$ & & $56(33.9)$ & & $31(18.8)$ & & $102(61.8)$ & \\
\hline Present (121) & $102(84.3)$ & & $67(55.4)$ & & $41(33.9)$ & & $80(66.1)$ & \\
\hline Perineural invasion & & 0.003 & & 0.006 & & 0.005 & & 0.817 \\
\hline Absent (214) & $146(68.2)$ & & $82(38.3)$ & & $45(21.0)$ & & $137(64.0)$ & \\
\hline Present (72) & $62(86.1)$ & & $41(56.9)$ & & $27(37.5)$ & & $45(62.5)$ & \\
\hline Lymph node metastasis & & $<0.001$ & & $<0.001$ & & 0.011 & & 0.839 \\
\hline Absent (160) & $103(64.4)$ & & $54(33.8)$ & & $31(19.4)$ & & $101(63.1)$ & \\
\hline Present (126) & $105(83.3)$ & & $69(54.8)$ & & $41(32.5)$ & & $81(64.3)$ & \\
\hline pTNM stage & & 0.001 & & 0.001 & & 0.009 & & 0.516 \\
\hline I and II (153) & $99(64.7)$ & & $52(34.0)$ & & $29(19.0)$ & & $100(65.4)$ & \\
\hline III and IV (133) & $109(82.0)$ & & $71(53.4)$ & & $43(32.3)$ & & $82(61.7)$ & \\
\hline $\begin{array}{l}\text { Recurrence or metastasis } \\
\text { after surgery }\end{array}$ & & 0.004 & & 0.110 & & 0.818 & & 0.095 \\
\hline Absent (233) & $161(69.1)$ & & $95(40.8)$ & & $58(24.9)$ & & $143(61.4)$ & \\
\hline Present (53) & 47 (88.7) & & $28(52.8)$ & & $14(26.4)$ & & $39(73.6)$ & \\
\hline $\begin{array}{l}\text { Recurrence or metastasis } \\
\text { after adjuvant chemotherapy }\end{array}$ & & 0.088 & & 0.457 & & 0.929 & & 0.123 \\
\hline Absent (46) & $33(71.7)$ & & $24(52.2)$ & & $17(37.0)$ & & $26(56.5)$ & \\
\hline Present (21) & $19(90.5)$ & & $13(61.9)$ & & $8(38.1)$ & & $16(76.2)$ & \\
\hline
\end{tabular}

in the tumor center significantly correlated with old age ( $\geq 60$ years, $P=0.038)$, female sex $(P=0.026)$, large tumor size ( $\geq 4 \mathrm{~cm}, \mathrm{P}=0.012$ ), poor differentiation $(\mathrm{P}<0.001)$, deeper invasion depth $(\mathrm{P}=0.048)$, presence of lymphovascular invasion $(\mathrm{P}=0.009)$, presence of perineural invasion $(\mathrm{P}=0.013)$, presence of lymph node metastasis $(\mathrm{P}<0.001)$ and advanced tumor stage $(\mathrm{P}<0.001)$ (Table I). Loss of E-cadherin expression in the invasive front significantly associated with large tumor size ( $\geq 4 \mathrm{~cm}, \mathrm{P}=0.011$ ), poor differentiation ( $\mathrm{P}=0.001$ ), deeper invasion depth $(\mathrm{P}=0.001)$, presence of lymphovascular invasion $(\mathrm{P}<0.001)$, presence of perineural invasion $(\mathrm{P}=0.003)$, presence of lymph node metastasis $(\mathrm{P}<0.001)$, advanced tumor 

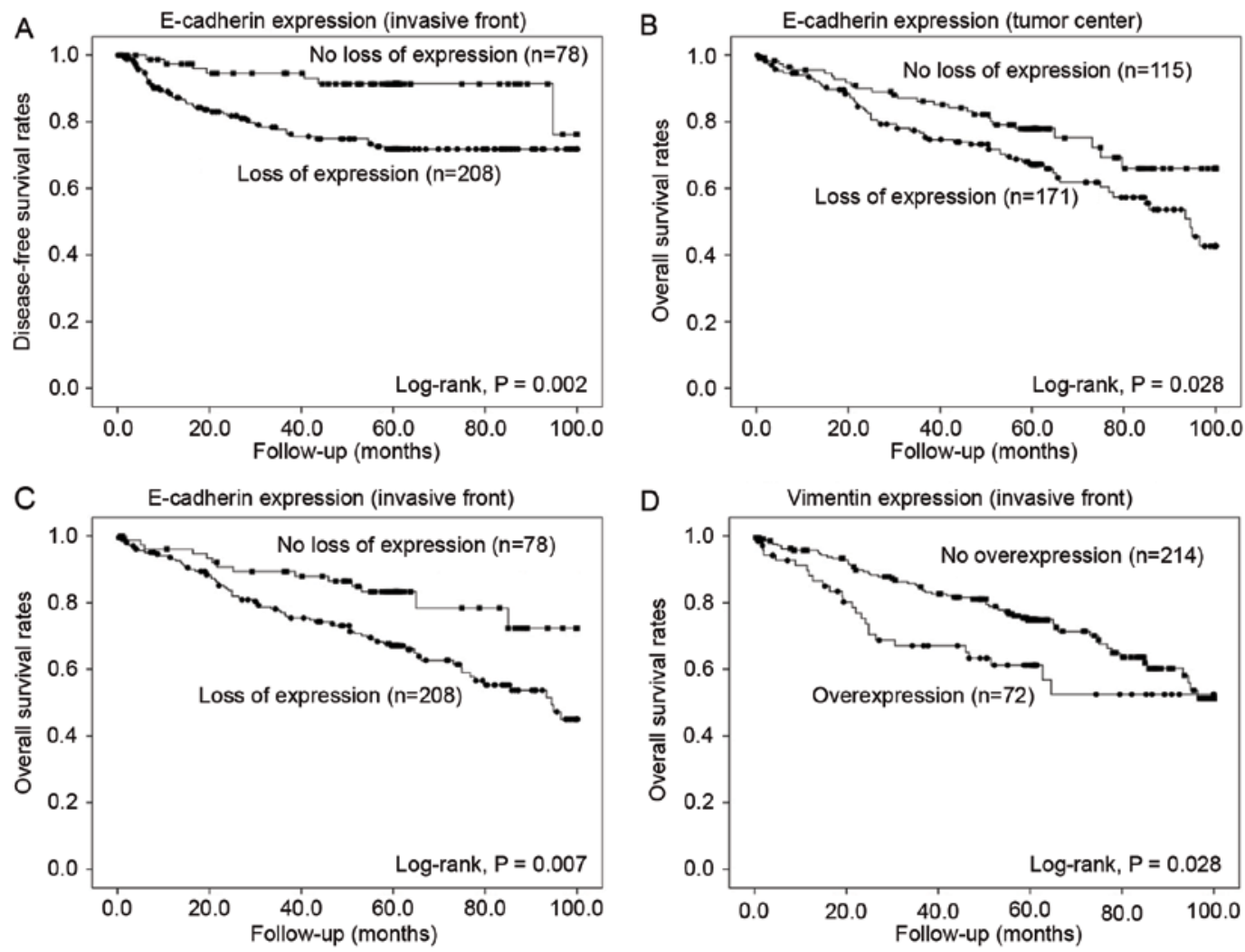

Figure 2. Kaplan-Meier survival analyses for the protein expression as determinant of disease-free survival (DFS) and overall survival (OS). (A) Loss of E-cadherin expression in the invasive front and DFS. (B) Loss of E-cadherin expression in the tumor center and OS. (C) Loss of E-cadherin expression in the invasive front and OS. (D) Vimentin overexpression in the invasive front and OS.

stage $(\mathrm{P}=0.001)$, and post-operative recurrence or metastasis $(\mathrm{P}=0.004)$ (Table II). The result of the Kaplan-Meier univariate analysis showed that a loss of E-cadherin expression in the tumor center significantly associated with poor OS ( $\mathrm{P}=0.028)$, but not DFS ( $\mathrm{P}=0.482)$ (Fig. 2). In the invasive front, loss of E-cadherin expression related with both shorter DFS ( $\mathrm{P}=0.002)$ and $\mathrm{OS}(\mathrm{P}=0.007)$ (Fig. 2).

$\beta$-catenin. $\beta$-catenin was strongly expressed in the membrane of non-neoplastic colorectal epithelial cells. CRC cells showed diffuse membranous expression or loss of membrane expression with aberrant cytoplasmic or nuclear expression (Fig. 1). The optimal cut-off score was determined as 95\%. In the tumor center, $184(64.3 \%)$ cases showed diffuse membranous staining and $102(35.7 \%)$ cases showed loss of membrane expression ( $<95 \%$ staining, as defined by ROC curve analysis). In the invasive front, $163(57.0 \%)$ cases showed diffuse membranous expression and 123 (43.0\%) showed loss of membrane expression. Loss of $\beta$-catenin expression in the tumor center significantly correlated with poor differentiation $(\mathrm{P}<0.001)$, presence of lymphovascular invasion $(\mathrm{P}=0.007)$, presence of lymph node metastasis $(\mathrm{P}=0.012)$, and advanced tumor stage $(\mathrm{P}=0.034)$ (Table I). Loss of $\beta$-catenin expression in the invasive front significantly associated with poor differentiation $(\mathrm{P}=0.004)$, presence of lymphovascular invasion $(\mathrm{P}<0.001)$, presence of perineural invasion $(\mathrm{P}=0.006)$, presence of lymph node metastasis $(\mathrm{P}<0.001)$ and advanced tumor stage $(\mathrm{P}=0.001)$ (Table II). Loss of membranous $\beta$-catenin expression in the tumor center did not associate with DFS or OS ( $\mathrm{P}=0.393$ and $\mathrm{P}=0.087$, respectively). In the invasive front, loss of $\beta$-catenin expression tended to associate with shorter DFS and OS $(\mathrm{P}=0.068$ and $\mathrm{P}=0.060$, respectively).

Vimentin. Vimentin was not expressed in non-neoplastic colorectal epithelial cells. In the CRC tissues, vimentin was overexpressed in the cytoplasm of the cancer cells (Fig. 1). The optimal cut-off score was determined as $5 \%$, based on ROC curve analysis. In the tumor center, 40 (14.0\%) cases showed overexpression of cytoplasmic vimentin. In the invasive front, $72(25.2 \%)$ cases showed vimentin overexpression. Overexpression of vimentin in the tumor center significantly related with female sex $(\mathrm{P}=0.010)$, poor differentiation $(\mathrm{P}<0.001)$, deeper invasion depth $(\mathrm{P}=0.038)$, presence of lymphovascular invasion $(\mathrm{P}=0.036)$, presence of perineural invasion $(\mathrm{P}<0.001)$, presence of lymph node metastasis $(\mathrm{P}=0.004)$ and advanced tumor stage $(\mathrm{P}=0.004)$ (Table I). In the invasive front, overexpression of vimentin significantly correlated with large tumor size ( $\geq 4 \mathrm{~cm}, \mathrm{P}=0.018)$, poor differentiation $(\mathrm{P}<0.001)$, deeper invasion depth $(\mathrm{P}=0.039)$, presence of lymphovascular invasion $(\mathrm{P}=0.004)$, presence of perineural invasion $(\mathrm{P}=0.005)$, presence of lymph node metastasis $(\mathrm{P}=0.011)$ and advanced tumor stage $(\mathrm{P}=0.009)$ (Table II). Overexpression of vimentin in the tumor center was not associated with DFS or OS $(\mathrm{P}=0.389$ and $\mathrm{P}=0.313$, respectively), whereas in the invasive front, overexpression of vimentin significantly correlated with poor OS $(\mathrm{P}=0.028)$ but not DFS ( $\mathrm{P}=0.359)$ (Fig. 2). 
Table III. Clinicopathological characteristics and correlation with the cancer stem cell (CSC)-related protein expression status in the tumor center.

\begin{tabular}{|c|c|c|c|c|}
\hline \multirow[b]{2}{*}{ Characteristics (n) } & \multicolumn{2}{|c|}{ Loss of expression } & \multicolumn{2}{|c|}{ Overexpression } \\
\hline & $\begin{array}{c}\text { CD44 } \\
(\mathrm{n}=119) \\
(\%)\end{array}$ & P-value & $\begin{array}{l}\text { CD133 } \\
(\mathrm{n}=93) \\
(\%)\end{array}$ & P-value \\
\hline Age (years) & & 0.649 & & 0.752 \\
\hline$<60$ (99) & $43(43.4)$ & & $31(31.3)$ & \\
\hline$\geq 60$ (187) & $76(40.6)$ & & $62(33.2)$ & \\
\hline Sex & & 0.009 & & 0.914 \\
\hline Female (112) & $36(32.1)$ & & $36(32.1)$ & \\
\hline Male (174) & $83(47.7)$ & & $57(32.8)$ & \\
\hline Size (cm) & & 0.117 & & 0.026 \\
\hline$<4$ (109) & $39(35.8)$ & & $44(40.4)$ & \\
\hline$\geq 4(177)$ & $80(45.2)$ & & $49(27.7)$ & \\
\hline Histologic grade & & 0.392 & & 0.716 \\
\hline Low (249) & $106(42.6)$ & & $80(32.1)$ & \\
\hline High (37) & $13(35.1)$ & & $13(35.1)$ & \\
\hline $\begin{array}{l}\text { Depth of invasion } \\
\text { (pT category) }\end{array}$ & & 0.002 & & 0.245 \\
\hline $\mathrm{T} 1$ or T2 $(65)$ & $16(24.6)$ & & $25(38.5)$ & \\
\hline T3 or T4 (221) & 103 (46.6) & & $68(30.8)$ & \\
\hline $\begin{array}{l}\text { Lymphovascular } \\
\text { invasion }\end{array}$ & & 0.519 & & 0.492 \\
\hline Absent (165) & $66(40.0)$ & & $51(30.9)$ & \\
\hline Present (121) & $53(43.8)$ & & $42(34.7)$ & \\
\hline Perineural invasion & & 0.012 & & 0.321 \\
\hline Absent (214) & $80(37.4)$ & & $73(34.1)$ & \\
\hline Present (72) & $39(54.2)$ & & $20(27.8)$ & \\
\hline $\begin{array}{l}\text { Lymph node } \\
\text { metastasis }\end{array}$ & & 0.005 & & 0.805 \\
\hline Absent (160) & $55(34.4)$ & & $53(33.1)$ & \\
\hline Present (126) & $64(50.8)$ & & $40(31.7)$ & \\
\hline pTNM stage & & 0.002 & & 0.569 \\
\hline I and II (153) & $51(33.3)$ & & $52(34.0)$ & \\
\hline III and IV (133) & $68(51.1)$ & & $41(30.8)$ & \\
\hline $\begin{array}{l}\text { Recurrence or } \\
\text { metastasis } \\
\text { after surgery }\end{array}$ & & 0.363 & & 0.369 \\
\hline Absent (233) & $94(40.3)$ & & $73(31.3)$ & \\
\hline Present (53) & $25(47.2)$ & & $20(37.7)$ & \\
\hline $\begin{array}{l}\text { Recurrence or } \\
\text { metastasis after } \\
\text { adjuvant } \\
\text { chemotherapy }\end{array}$ & & 0.987 & & 0.220 \\
\hline Absent (46) & $24(52.2)$ & & $9(19.6)$ & \\
\hline Present (21) & $11(52.4)$ & & $7(33.3)$ & \\
\hline
\end{tabular}

Snail. Snail was not expressed in non-neoplastic colorectal epithelial cells. In the CRC cells, snail loss or overexpression was observed in the cytoplasm and/or nucleus (Fig. 1). The optimal cut-off score was determined as 5\%, based on ROC curve analysis. Loss of snail expression in the tumor center was observed in 137 (47.9\%) cases, and in the invasive front in $104(31.3 \%)$ cases. Snail overexpression in the tumor center was identified in $149(52.1 \%)$ cases and in the invasive front in $182(68.7 \%)$ cases. Snail overexpression tended to associate with superficial invasion depth both in the tumor center and in the invasive front $(\mathrm{P}=0.044$ and $\mathrm{P}=0.052$, respectively) (Tables I and II). Neither loss of expression nor overexpression of snail in the tumor center or in the invasive front was significantly associated with survival time.

CD44. CD44 was not expressed in non-neoplastic colorectal epithelial cells, whereas membranous expression was seen in the CRC cells (Fig. 1). Of the analyzed tumors, 119 (58.4\%) cases showed loss of CD44 and 167 (58.4\%) showed overexpression in the tumor center. In the invasive front, $189(66.1 \%)$ cases showed loss of expression and 97 (33.9\%) cases showed overexpression. The optimal cut-off score was determined as $5 \%$, based on ROC curve analysis. Loss of CD44 expression in the tumor center significantly correlated with male sex $(\mathrm{P}=0.009)$, deeper invasion depth $(\mathrm{P}=0.002)$, presence of perineural invasion $(\mathrm{P}=0.012)$, presence of lymph node metastasis $(\mathrm{P}=0.005)$ and advanced tumor stage $(\mathrm{P}=0.002)$ (Table III). In the invasive front, loss of CD44 expression significantly associated with deeper invasion depth $(\mathrm{P}=0.001)$, presence of lymph node metastasis $(\mathrm{P}<0.001)$ and advanced tumor stage $(\mathrm{P}<0.001)$ (Table IV). No association between loss of CD44 expression and DFS or OS was noted in either the tumor center or invasive front.

CD133. CD133 was not expressed in non-neoplastic colorectal epithelial cells. In the CRC cells, CD133 loss or overexpression was seen in either the apical portion of the tumor cells or the shed cellular debris in the tumor glands (Fig. 1). Loss of CD133 expression in the tumor center was observed in $195(67.5 \%)$ cases and in the invasive front in $229(80.1 \%)$ cases. Overexpression of CD133 in the tumor center was observed in $93(32.5 \%)$ cases and in the invasive front in 57 (19.9\%) cases. The optimal cut-off score, based on ROC curve analysis, was determined as $5 \%$. In the tumor center, overexpression of CD133 significantly correlated with small tumor size $(<4 \mathrm{~cm}$, $\mathrm{P}=0.026)$. No other clinicopathologic features related with CD133 overexpression, both in the tumor center and in the invasive front (Tables III and IV). Furthermore, neither in the tumor center nor in the invasive front did loss of expression or overexpression of CD133 significantly associate with DFS or OS.

Multi-marker combinations for predicting patient outcome. Based on the correlation between the cumulative altered expression of the EMT- and CSC-related proteins and the tumor behavior of $\mathrm{CRC}$, we performed univariate survival analyses on a total of 66 combinations of the expression of 6 markers. To determine the most accurate combination for predicting patient prognosis, 5 markers (E-cadherin, $\beta$-catenin, vimentin, snail and CD133) and the possible combinations thereof that had the lowest P-values in the univariate survival analysis using the Kaplan-Meier method were selected. For statistical 
Table IV. Clinicopathological characteristics and correlation with the cancer stem cell (CSC)-related protein expression status in the invasive front.

\begin{tabular}{|c|c|c|c|c|}
\hline \multirow[b]{2}{*}{ Characteristics (n) } & \multicolumn{2}{|c|}{ Loss of expression } & \multicolumn{2}{|c|}{ Overexpression } \\
\hline & $\begin{array}{c}\text { CD44 } \\
(\mathrm{n}=189) \\
(\%)\end{array}$ & P-value & $\begin{array}{c}\text { CD133 } \\
(\mathrm{n}=57) \\
(\%)\end{array}$ & P-value \\
\hline Age (years) & & 0.709 & & 0.933 \\
\hline$<60$ (99) & 64 (64.6) & & $20(20.2)$ & \\
\hline$\geq 60(187)$ & $125(66.8)$ & & $37(19.8)$ & \\
\hline Sex & & 0.124 & & 0.611 \\
\hline Female (112) & $68(60.7)$ & & $24(21.4)$ & \\
\hline Male (174) & $121(69.5)$ & & $33(19.0)$ & \\
\hline Size (cm) & & 0.436 & & 0.318 \\
\hline$<4(109)$ & $69(63.3)$ & & $25(22.9)$ & \\
\hline$\geq 4$ (177) & $120(67.8)$ & & $32(18.1)$ & \\
\hline Histologic grade & & 0.199 & & 0.544 \\
\hline Low (249) & $168(67.5)$ & & $51(20.5)$ & \\
\hline High (37) & $21(56.8)$ & & $6(16.2)$ & \\
\hline $\begin{array}{l}\text { Depth of invasion } \\
\text { (pT category) }\end{array}$ & & 0.001 & & 0.712 \\
\hline $\mathrm{T} 1$ or T2 (65) & $32(49.2)$ & & $14(21.5)$ & \\
\hline $\mathrm{T} 3$ or T4 (221) & $157(71.0)$ & & $43(19.5)$ & \\
\hline $\begin{array}{l}\text { Lymphovascular } \\
\text { invasion }\end{array}$ & & 0.307 & & 0.738 \\
\hline Absent (165) & $105(63.6)$ & & 34 (20.6) & \\
\hline Present (121) & $84(69.4)$ & & $23(19.0)$ & \\
\hline $\begin{array}{l}\text { Perineural } \\
\text { invasion }\end{array}$ & & 0.325 & & 0.253 \\
\hline Absent (214) & $138(64.5)$ & & $46(21.5)$ & \\
\hline Present (72) & $51(70.8)$ & & $11(15.3)$ & \\
\hline $\begin{array}{l}\text { Lymph node } \\
\text { metastasis }\end{array}$ & & $<0.001$ & & 0.068 \\
\hline Absent (160) & $91(56.9)$ & & $38(23.8)$ & \\
\hline Present (126) & $98(77.8)$ & & $19(15.1)$ & \\
\hline pTNM stage & & $<0.001$ & & 0.102 \\
\hline I and II (153) & $86(56.2)$ & & $36(23.5)$ & \\
\hline III and IV (133) & $103(77.4)$ & & $21(15.8)$ & \\
\hline $\begin{array}{l}\text { Recurrence or } \\
\text { metastasis after } \\
\text { surgery }\end{array}$ & & 0.525 & & 0.552 \\
\hline Absent (233) & $152(65.2)$ & & $48(20.6)$ & \\
\hline Present (53) & $37(69.8)$ & & $9(17.0)$ & \\
\hline $\begin{array}{l}\text { Recurrence or } \\
\text { metastasis after } \\
\text { adjuvant } \\
\text { chemotherapy }\end{array}$ & & 0.953 & & 0.689 \\
\hline Absent (46) & $31(67.4)$ & & $5(10.9)$ & \\
\hline Present (21) & 14 (66.7) & & $3(14.3)$ & \\
\hline
\end{tabular}
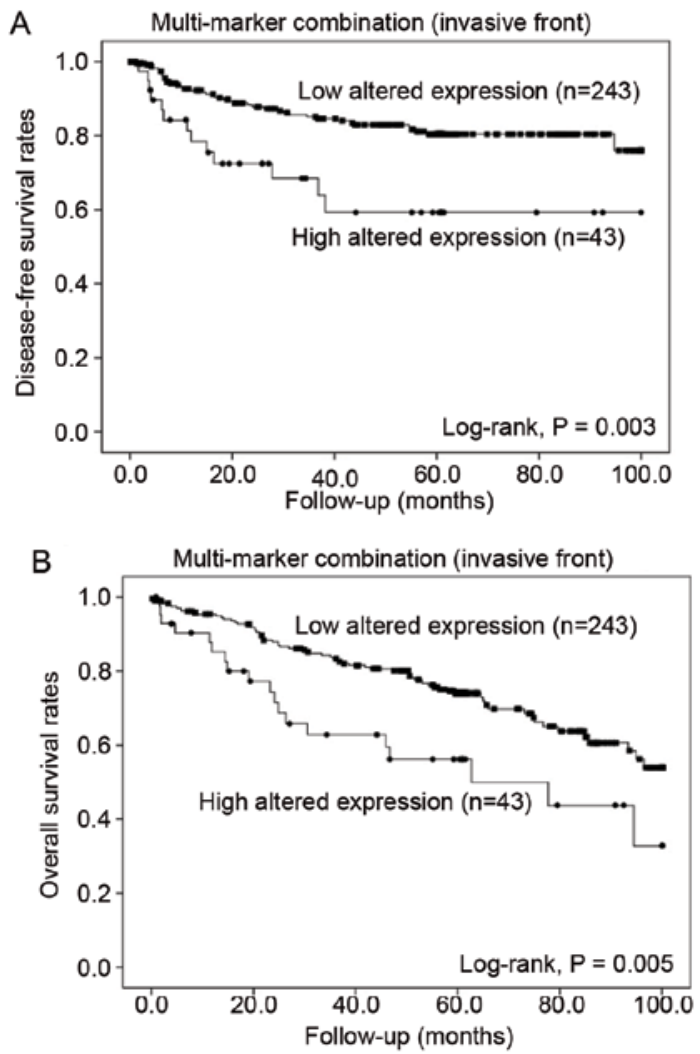

Figure 3. Kaplan-Meier survival analyses of the combination of 5 epithelialmesenchymal transition (EMT)-related and cancer stem cell (CSC)-related expression of protein in the invasive front as a determinant of (A) diseasefree survival (DFS) and (B) overall survival (OS). Significant decrease in the high number of altered protein expression group compared with the low number of altered protein expression group were observed.

analysis, the cases were classified into 2 groups according to the number of cases with altered protein expression. A total of 254 cases $(88.8 \%)$ in the tumor center and 243 cases $(85.0 \%)$ in the invasive front were designated as having a 'low number of altered protein expression', that is, altered expressions of no more than 3 proteins. Thirty-two cases (11.2\%) in the tumor center and 43 cases $(15.0 \%)$ in the invasive front were designated as having a 'high number of altered protein expression', classified as altered expression of 4 or 5 proteins. In the tumor center, a high number of altered protein expression significantly correlated with poor differentiation $(\mathrm{P}=0.007)$, presence of perineural invasion $(\mathrm{P}=0.010)$ and presence of lymph node metastasis $(\mathrm{P}=0.026)$. In the invasive front, a high number of altered protein expression significantly associated with poor differentiation $(\mathrm{P}=0.007)$, presence of lymphovascular invasion $(\mathrm{P}=0.001)$, presence of perineural invasion $(\mathrm{P}=0.006)$, presence of lymph node metastasis $(\mathrm{P}<0.001)$, advanced tumor stage $(\mathrm{P}<0.001)$ and post-operative recurrence or metastasis $(\mathrm{P}=0.032)($ Table $\mathrm{V})$

The Kaplan-Meier univariate survival analysis indicated that the mean DFS and OS were significantly shortened in patients with a high number of altered protein expression in the invasive front compared to in those with a low number of altered protein expressions (DFS, 66.2 vs. 84.6 months, $\mathrm{P}=0.003$; OS, 60.8 vs. 77.9 months, $\mathrm{P}=0.005$ ) (Fig. 3). In the tumor center, no significant difference was found according to the number of altered protein expression. Despite this adverse 
Table V. Clinicopathological correlation between low- and high- expression according to the number of altered protein expression, E-cadherin, $\beta$-catenin, vimentin, snail and CD133 altered expression in the tumor center and invasive front.

\begin{tabular}{|c|c|c|c|c|c|c|}
\hline \multirow[b]{2}{*}{ Characteristics (n) } & \multicolumn{3}{|c|}{ Tumor center } & \multicolumn{3}{|c|}{ Invasive front } \\
\hline & $\begin{array}{c}\text { Low } \\
(\mathrm{N}=254)(\%)\end{array}$ & $\begin{array}{c}\text { High } \\
(\mathrm{N}=32)(\%)\end{array}$ & P-value & $\begin{array}{c}\text { Low } \\
(\mathrm{N}=243)(\%)\end{array}$ & $\begin{array}{c}\text { High } \\
(\mathrm{N}=43)(\%)\end{array}$ & P-value \\
\hline Age (years) & & & 0.413 & & & 0.698 \\
\hline$<60(99)$ & $90(35.4)$ & $9(28.1)$ & & $83(34.2)$ & $16(37.2)$ & \\
\hline$\geq 60(187)$ & $164(64.6)$ & $23(71.9)$ & & $160(65.8)$ & $27(62.8)$ & \\
\hline Sex & & & 0.838 & & & 0.957 \\
\hline Female (112) & $100(39.4)$ & $12(37.5)$ & & $95(39.1)$ & $17(39.5)$ & \\
\hline Male (174) & $154(60.6)$ & $20(62.5)$ & & $148(60.9)$ & $26(60.5)$ & \\
\hline Size $(\mathrm{cm})$ & & & 0.940 & & & 0.248 \\
\hline$<4(109)$ & 97 (38.2) & $12(37.5)$ & & $96(39.5)$ & $13(30.2)$ & \\
\hline$\geq 4(177)$ & $157(61.8)$ & $20(62.5)$ & & $147(60.5)$ & $30(69.8)$ & \\
\hline Histologic grade & & & 0.007 & & & 0.007 \\
\hline Low (249) & $226(89.0)$ & $23(71.9)$ & & $217(89.3)$ & $32(74.4)$ & \\
\hline High (37) & $28(11.0)$ & $9(28.1)$ & & $26(10.7)$ & $11(25.6)$ & \\
\hline Depth of invasion (pT category) & & & 0.745 & & & 0.274 \\
\hline $\mathrm{T} 1$ or $\mathrm{T} 2(65)$ & $57(22.4)$ & $8(25.0)$ & & $58(23.9)$ & $7(16.3)$ & \\
\hline $\mathrm{T} 3$ or T4 (221) & 197 (77.6) & $24(75.0)$ & & $185(76.1)$ & $36(83.7)$ & \\
\hline Lymphovascular invasion & & & 0.350 & & & 0.001 \\
\hline Absent (165) & $149(58.7)$ & $16(50.0)$ & & $150(61.7)$ & $15(34.9)$ & \\
\hline Present (121) & $105(41.3)$ & $16(50.0)$ & & $93(38.3)$ & $28(65.1)$ & \\
\hline Perineural invasion & & & 0.010 & & & 0.006 \\
\hline Absent (214) & $196(77.2)$ & $18(56.3)$ & & $189(77.8)$ & $25(58.1)$ & \\
\hline Present (72) & $58(22.8)$ & $14(43.8)$ & & $54(22.2)$ & $18(41.9)$ & \\
\hline Lymph node metastasis & & & 0.026 & & & $<0.001$ \\
\hline Absent (160) & $148(58.3)$ & $12(37.5)$ & & $148(60.9)$ & $12(27.9)$ & \\
\hline Present (126) & $106(41.7)$ & $20(62.5)$ & & $95(39.1)$ & $31(72.1)$ & \\
\hline pTNM stage & & & 0.054 & & & $<0.001$ \\
\hline I and II (153) & $141(55.5)$ & $12(37.5)$ & & $141(58.0)$ & $12(27.9)$ & \\
\hline III and IV (133) & $113(44.5)$ & $20(62.5)$ & & $102(42.0)$ & $31(72.1)$ & \\
\hline Recurrence or metastasis after surgery & & & 0.605 & & & 0.032 \\
\hline Absent (233) & $208(81.9)$ & $25(78.1)$ & & $203(83.5)$ & $30(69.8)$ & \\
\hline Present (53) & $46(18.1)$ & 7 (21.9) & & $40(16.5)$ & $13(30.2)$ & \\
\hline $\begin{array}{l}\text { Recurrence or metastasis after } \\
\text { adjuvant chemotherapy }\end{array}$ & & & 0.522 & & & 0.312 \\
\hline Absent (46) & $40(70.2)$ & $6(60.0)$ & & $36(72.0)$ & $10(58.8)$ & \\
\hline Present (21) & $17(29.8)$ & $4(40.0)$ & & $14(28.0)$ & 7 (41.2) & \\
\hline
\end{tabular}

effect observed in the univariate analysis, the prognostic value of a high number of altered protein expression did not remain as an independent prognostic indicator in the multivariate analysis.

\section{Discussion}

The multi-marker combination analysis of the altered protein expression of E-cadherin, $\beta$-catenin, vimentin, snail and CD133 in the invasive front showed more significant correlation with DFS $(\mathrm{P}=0.003)$ and $\mathrm{OS}(\mathrm{P}=0.005)$ than the single protein data. These results are similar to those reported in a previous study on EMT- and CSC-related proteins in gastric cancer (4). Notably, in that study, a combination of 4 proteins ( $\beta$-catenin, vimentin, snail and CD133), although each was not individually correlated with DFS, significantly correlated with DFS $(\mathrm{P}=0.005)$ and $\mathrm{OS}(\mathrm{P}=0.007)$. Thus, concurrent alterations of EMT- and CSC-related markers may have a greater effect on the biological behavior of CRC than the alteration of a single EMT- or CSC-related protein. Further 
evaluation for optimal selection of protein combinations is needed for accurate prediction of patient outcomes and for aiding in the clinicopathological diagnosis; based on our results, a combination of E-cadherin, $\beta$-catenin, vimentin, snail and CD133 seems to be a possible candidate.

To determine the role of EMT in CRC progression and patient survival, the altered expression status of 4 EMT-related markers, their association with clinicopathological characteristics and patient outcomes were analyzed. Some studies have demonstrated that altered EMT-related protein expression was more frequently observed in the invasive front and that EMT occurs at the invasive front $(16,19)$. Ye et al $(27)$ further demonstrated that expression of EMT markers is often observed among carcinoma cells that are closely opposed to stromal cells, and a variety of stromal cell-derived signals synergize with one another to induce and maintain EMT in primary tumors. In the present study, altered expression of all EMT-related proteins was more frequently observed in the invasive front than in the tumor center. In addition, the altered expression of all EMT-related proteins, except snail, significantly associated with unfavorable clinicopathological factors in both the tumor center and the invasive front. According to previous studies, altered expression of EMT-related markers associates with tumor size, differentiation, growth patterns, metastasis and poor prognosis $(17,18,28)$. In this study, loss of E-cadherin expression in the invasive front significantly associated with poor OS $(\mathrm{P}=0.007)$ and showed a better $\mathrm{P}$-value compared with in the tumor center $(\mathrm{P}=0.028)$. In addition to correlating with OS, loss of E-cadherin expression in the invasive front significantly associated with shorter DFS $(\mathrm{P}=0.002)$, whereas this was not observed for its expression in the tumor center. Similarly, overexpression of vimentin in the invasive front, but not in the tumor center, also significantly correlated with $\mathrm{OS}(\mathrm{P}=0.028)$. These findings support the model that EMT may occur in the invasive front and associates with poor prognosis. Thus, identification of altered expression of EMT-related proteins, especially in the invasive front, is important to predict the aggressive nature of the tumor and the prognosis of the patient.

Despite CD44 and CD133 being the most extensively researched colorectal CSC markers $(29,30)$, some controversies still exist over the relationship between CD44 and CD133 expression and their associations with clinicopathological factors and patient outcome (26,31-34). Recently, Zhou et al (35) reported that CD $44^{\text {high }} / \mathrm{CD} 133^{\text {high }}$ colon cancer cells harbor CSC properties that may be related to the tumor growth of colon cancer. However, in the present study, loss of CD44 expression significantly correlated with aggressive tumor characteristics while altered expression of CD133 did not relate with any tumor characteristics or with the patient survival time. Similar to the results in the present study, Lugli et al (25) demonstrated that loss of CD44 expression was linked to more advanced T classification, lymph node involvement, presence of vascular invasion, and an infiltrating tumor border, whereas neither overexpression nor loss of CD133 significantly associated with tumor progression or the survival time. The discrepancies among the previous studies and present study might be explained by differences in the selected tumor tissue (whole tumor, representative tumor center, or invasive front), as CSC-related proteins, especially CD44, show heterogeneous expression throughout the tumor (25). In addition, it might be also explained by the use of different methodologies and different antibodies, and/or by the differences in the number of cases investigated.

In conclusion, the present study found that altered expressions of EMT-related proteins, as single markers, significantly correlated with several unfavorable clinicopathological factors and poor patient survival, especially in the invasive front area. For the CSC-related proteins, loss of CD44 expression was associated with unfavorable clinicopathological factors, whereas altered expression of CD133 did not. However, combined expressions of altered EMT- and CSC-related proteins strongly associated with unfavorable clinicopathological factors and poor patient outcomes. Besides serving as potential biomarkers for aggressive tumor behavior and tumor recurrence or metastasis, cancer cells expressing combined EMT- and CSC-related proteins may represent possible candidates for molecular targeted treatments for CRC in the future. Further studies are needed to elucidate the relationships and molecular pathways between EMT and CSCs in CRC.

\section{Acknowledgements}

The present study was supported by the National Research Foundation of Korea (NRF) grant funded by the Korean Government (MSIP) (no. 2008-0062279). Tissue samples were provided by the Chonbuk National University Hospital, a member of the National Biobank of Korea, which is supported by the Ministry of Health, Welfare and Family Affairs.

\section{References}

1. Fitzmaurice C, Dicker D, Pain A, Hamavid H, Moradi-Lakeh M, MacIntyre MF, Allen C, Hansen G, Woodbrook R, Wolfe C, et al; Global Burden of Disease Cancer Collaboration: The global burden of cancer 2013. JAMA Oncol 1: 505-527, 2015.

2. Thiery JP and Sleeman JP: Complex networks orchestrate epithelial-mesenchymal transitions. Nat Rev Mol Cell Biol 7: 131-142, 2006.

3. Hollier BG, Evans K and Mani SA: The epithelial-to-mesenchymal transition and cancer stem cells: A coalition against cancer therapies. J Mammary Gland Biol Neoplasia 14: 29-43, 2009.

4. Ryu HS, Park DJ, Kim HH, Kim WH and Lee HS: Combination of epithelial-mesenchymal transition and cancer stem cell-like phenotypes has independent prognostic value in gastric cancer. Hum Pathol 43: 520-528, 2012.

5. Bezdekova M, Brychtova S, Sedlakova E, Langova K, Brychta T and Belej K: Analysis of Snail-1, E-cadherin and claudin-1 expression in colorectal adenomas and carcinomas. Int J Mol Sci 13: 1632-1643, 2012.

6. Mitselou A, Galani V, Skoufi U, Arvanitis DL, Lampri E and Ioachim E: Syndecan-1, epithelial-mesenchymal transition markers (E-cadherin/beta-catenin) and neoangiogenesis-related proteins (PCAM-1 and Endoglin) in colorectal cancer. Anticancer Res 36: 2271-2280, 2016.

7. Batlle E, Sancho E, Francí C, Domínguez D, Monfar M, Baulida J and García De Herreros A: The transcription factor snail is a repressor of E-cadherin gene expression in epithelial tumour cells. Nat Cell Biol 2: 84-89, 2000.

8. Geiger TR and Peeper DS: Metastasis mechanisms. Biochim Biophys Acta 1796: 293-308, 2009.

9. Findlay VJ, Wang C, Watson DK and Camp ER: Epithelial-tomesenchymal transition and the cancer stem cell phenotype: Insights from cancer biology with therapeutic implications for colorectal cancer. Cancer Gene Ther 21: 181-187, 2014.

10. Kajiyama H, Shibata K, Terauchi M, Yamashita M, Ino K, Nawa A and Kikkawa F: Chemoresistance to paclitaxel induces epithelial-mesenchymal transition and enhances metastatic potential for epithelial ovarian carcinoma cells. Int J Oncol 31: 277-283, 2007. 
11. Yang AD, Fan F, Camp ER, van Buren G, Liu W, Somcio R, Gray MJ, Cheng H, Hoff PM and Ellis LM: Chronic oxaliplatin resistance induces epithelial-to-mesenchymal transition in colorectal cancer cell lines. Clin Cancer Res 12: 4147-4153, 2006.

12. Mitra A, Mishra L and Li S: EMT, CTCs and CSCs in tumor relapse and drug-resistance. Oncotarget 6: 10697-10711, 2015.

13. Thiery JP, Acloque H, Huang RY and Nieto MA: Epithelialmesenchymal transitions in development and disease. Cell 139: 871-890, 2009.

14. Shioiri M, Shida T, Koda K, Oda K, Seike K, Nishimura M, Takano S and Miyazaki M: Slug expression is an independent prognostic parameter for poor survival in colorectal carcinoma patients. Br J Cancer 94: 1816-1822, 2006.

15. Kroepil F, Fluegen G, Vallböhmer D, Baldus SE, Dizdar L, Raffel AM, Hafner D, Stoecklein NH and Knoefel WT: Snaill expression in colorectal cancer and its correlation with clinical and pathological parameters. BMC Cancer 13: 145, 2013.

16. Brabletz T, Jung A, Reu S, Porzner M, Hlubek F, KunzSchughart LA, Knuechel R and Kirchner T: Variable beta-catenin expression in colorectal cancers indicates tumor progression driven by the tumor environment. Proc Natl Acad Sci USA 98 10356-10361, 2001.

17. Ngan CY, Yamamoto H, Seshimo I, Ezumi K, Terayama M, Hemmi H, Takemasa I, Ikeda M, Sekimoto M and Monden M: A multivariate analysis of adhesion molecules expression in assessment of colorectal cancer. J Surg Oncol 95: 652-662, 2007

18. Gagliardi G, Kandemir O, Liu D, Guida M, Benvestito S, Ruers TG, Benjamin IS, Northover JM, Stamp GW, Talbot IC, et al: Changes in E-cadherin immunoreactivity in the adenomacarcinoma sequence of the large bowel. Virchows Arch 426: $149-154,1995$.

19. Rosivatz E, Becker I, Bamba M, Schott C, Diebold J, Mayr D, Höfler $\mathrm{H}$ and Becker KF: Neoexpression of N-cadherin in E-cadherin positive colon cancers. Int J Cancer 111: 711-719, 2004

20. Fanali C, Lucchetti D, Farina M, Corbi M, Cufino V, Cittadini A and Sgambato A: Cancer stem cells in colorectal cancer from pathogenesis to therapy: Controversies and perspectives. World J Gastroenterol 20: 923-942, 2014.

21. Hong I, Hong SW, Chang YG, Lee WY, Lee B, Kang YK, Kim YS, Paik IW and Lee H: Expression of the cancer stem cell markers CD44 and CD133 in colorectal cancer: An immunohistochemical staining analysis. Ann Coloproctol 31: 84-91, 2015.

22. Cherciu I, Bărbălan A, Pirici D, Mărgăritescu C and Săftoiu A Stem cells, colorectal cancer and cancer stem cell markers correlations. Curr Health Sci J 40: 153-161, 2014.

23. Hamilton SR, Bosman FT and Boffetta P: Carcinoma of the colon and rectum. In: WHO Classification of Tumours of the Digestive System. 4th edition. Bosman FT, Carneiro F, Hruban RH and Theise ND (eds). IARC Press, Lyon, pp132-146, 2010.
24. Edge SB, Byrd DR, Compton CC, Fritz AG, Greene FL and Trotti A: AJCC Cancer Staging manual. 7th edition. Springer, New York, NY, pp237-246, 2010.

25. Lugli A, Iezzi G, Hostettler I, Muraro MG, Mele V, Tornillo L, Carafa V, Spagnoli G, Terracciano L and Zlobec I: Prognostic impact of the expression of putative cancer stem cell markers CD133, CD166, CD44s, EpCAM, and ALDH1 in colorectal cancer. Br J Cancer 103: 382-390, 2010.

26. Horst D, Kriegl L, Engel J, Kirchner T and Jung A: CD133 expression is an independent prognostic marker for low survival in colorectal cancer. Br J Cancer 99: 1285-1289, 2008.

27. Ye X and Weinberg RA: Epithelial-mesenchymal plasticity: A central regulator of cancer progression. Trends Cell Biol 25: 675-686, 2015

28. Fan F, Samuel S, Evans KW, Lu J, Xia L, Zhou Y, Sceusi E, Tozzi F, Ye XC, Mani SA, et al: Overexpression of snail induces epithelial-mesenchymal transition and a cancer stem cell-like phenotype in human colorectal cancer cells. Cancer Med 1: 5-16, 2012.

29. Dalerba P, Dylla SJ, Park IK, Liu R, Wang X, Cho RW, Hoey T, Gurney A, Huang EH, Simeone DM, et al: Phenotypic characterization of human colorectal cancer stem cells. Proc Natl Acad Sci USA 104: 10158-10163, 2007.

30. Ricci-Vitiani L, Lombardi DG, Pilozzi E, Biffoni M, Todaro M, Peschle $C$ and De Maria R: Identification and expansion of human colon-cancer-initiating cells. Nature 445: 111-115, 2007.

31. Horst D, Scheel SK, Liebmann S, Neumann J, Maatz S, Kirchner T and Jung A: The cancer stem cell marker CD133 has high prognostic impact but unknown functional relevance for the metastasis of human colon cancer. J Pathol 219: 427-434, 2009.

32. Choi D, Lee HW, Hur KY, Kim JJ, Park GS, Jang SH, Song YS, Jang KS and Paik SS: Cancer stem cell markers CD133 and CD24 correlate with invasiveness and differentiation in colorectal adenocarcinoma. World J Gastroenterol 15: 2258-2264, 2009.

33. Huh JW, Kim HR, Kim YJ, Lee JH, Park YS, Cho SH and Joo JK: Expression of standard CD44 in human colorectal carcinoma: Association with prognosis. Pathol Int 59: 241-246, 2009.

34. Zavrides HN, Zizi-Sermpetzoglou A, Panousopoulos D, Athanasas G, Elemenoglou I and Peros G: Prognostic evaluation of CD44 expression in correlation with bcl-2 and p53 in colorectal cancer. Folia Histochem Cytobiol 43: 31-36, 2005.

35. Zhou JY, Chen M, Ma L, Wang X, Chen YG and Liu SL: Role of $\mathrm{CD} 44^{\text {high }} / \mathrm{CD} 133^{\text {high }} \mathrm{HCT}-116$ cells in the tumorigenesis of colon cancer. Oncotarget 7: 7657-7666, 2016. 